\title{
Electrocardiographic Alterations in Patients with Common Variable Immune Deficiency
}

\author{
Yaygın Değișken İmmün Yetmezliği Olan Hastalarda Elektrokardiyografik \\ Değişikliklerin Değerlendirilmesi
}

\author{
(D) Yakup Alsancak1 1 (1) Fatih Çölkesen² \\ ${ }^{1}$ Necmettin Erbakan University Meram Faculty of Medicine, Department of Cardiology, Konya, Turkey \\ ${ }^{2}$ Necmettin Erbakan University Meram Faculty of Medicine, Department of Clinical Immunology and Allergy, Konya, Turkey
}

\begin{abstract}
Introduction: Common variable immunodeficiency (CVID) is the most heterogeneous group among the antibody deficiency syndromes, but its effects on the cardiovascular system have not yet been clearly identified. Here, we aimed to investigate the arrhythmogenic effects of this disease with electrocardiography.

Methods: The study included 30 CVID patients and 30 control subjects matched for age and comorbidities. Electrocardiographic and echocardiographic values of all participants were recorded. QRS, QT, Tp-e were measured manually. QTc was calculated using Bazett's formula. Then, Tp-e/QT, Tp-e/QTc, QT/QRS, and QTc/QRS ratios were calculated and compared between the groups.

Results: PR interval and P-wave dispersion were found to be higher in the CVID group. In addition, the QT interval and corrected QT interval, T peak-to-end interval were higher in the CVID arm, and the index of cardiac electrophysiological balance value obtained with the QT/QRS ratio was also higher in the CVID group. The number of patients with $P$ terminal force was also higher in the CVID group.

Conclusion: As a result of this study, it was found that CVID patients have a higher incidence of developing arrhythmia than normal healthy individuals.
\end{abstract}

öZ

Amaç: Ortak değişken immün yetmezlik (CVID), antikor eksikliği sendromları arasında en heterojen gruptur, ancak kardiyovasküler sistem üzerindeki etkileri henüz net bir şekilde tanımlanamamıștır. Burada, bu hastalığın olası aritmojenik etkilerini, elektrokardiyografi ile değerlendirmeyi amaçladık.

Yöntemler: Çalışmaya 30 CVID hastası ile yaş ve komorbiditeleri eșleșen 30 gönüllü kontrol grubu dahil edildi. Tüm katılımcıların elektrokardiyografik ve ekokardiyografik değerleri kaydedildi. QRS, QT, Tp-e manuel olarak ölçüldü. QTC, Bazett formülü kullanılarak hesaplandı. Daha sonra, Tp-e/QT, Tp-e/QTc, QT/QRS ve QTc/QRS oranları hesaplandı ve gruplar arasında karşılaştırılma yapıldı.

Bulgular: CVID grubunda PR aralığı ve $\mathrm{P}$ dalga dispersiyonu daha yüksek bulundu. Ayrıca, QT aralığı ve düzeltilmiş QT aralığı, T peak-to-end interval, CVID kolunda daha yüksekti ve QT/QRS oranı ile elde edilen kardiyak elektrofizyolojik denge indeksi değeri CVID grubunda da daha yüksekti. CVID grubunda P terminal kuvveti olan hasta sayısı da daha fazla idi. Sonuç: Bu çalışma sonucunda, CVID hastalarının normal sağlıklı bireylere göre aritmi gelișme sıklığının daha yüksek olabileceği bulunmuștur.

Anahtar Kelimeler: Aritmi, CVID, elektrokardiyografi

Keywords: Arrhythmia, CVID, electrocardiography

\section{Introduction}

Common variable immunodeficiency (CVID) is the most heterogeneous group among the antibody deficiency syndromes and the estimated prevalence is about 1:25.000 (1). Hypogammaglobulinemia is a primary immunodeficiency characterized by recurrent infections and increased risk of developing autoimmune diseases and malignancy (2). The presence of concomitant autoimmune diseases or chronic diseases has been associated with chronic inflammatory processes in patients (3). However, its effects on the cardiovascular system have not yet been clearly identified (4). However, it may be associated with immune deficiencies due to the known effects of systemic inflammation in the pathogenesis of atherosclerosis (5). In addition, inflammation plays a significant role in the pathogenesis of chronic arrhythmias, such as atrial fibrillation (AF) $(6,7)$.

Standard surface electrocardiography is a simple diagnostic tool that is widely used in the detection of cardiac arrhythmias or coronary artery disease and in the evaluation of myocardial pathologies. Here, various

Cite this article as/Atıf: Alsancak Y, Çölkesen F. Electrocardiographic Alterations in Patients with Common Variable Immune Deficiency. İstanbul Med J 2020; 21(2): 109-14.

(c) Copyright 2020 by the University of Health Sciences Turkey, Istanbul Training and Research Hospital/Istanbul Medical Journal published by Galenos Publishing House.

(C) Telif Hakkı 2020 Sağıı Bilimleri Üniversitesi Istanbul Ĕgitim ve Araştırma Hastanesi/Istanbul Tıp Dergisi, Galenos Yayınevi tarafından basılmıștır. 
parameters have been identified on an electrocardiogram (ECG) that predicts sudden cardiac death or any arrhythmias. The best known of these is the prolongation of the QT interval, indicating sudden death or cardiac electrical instability (8). In addition, the T-wave peak-to-end $\left(\mathrm{T}_{\mathrm{p}-\mathrm{e}}\right)$ interval and $\mathrm{T}_{\mathrm{p}-\mathrm{e}} / \mathrm{QT}$ ratio are novel proarrhythmogenic markers suggesting transmural dispersion of repolarization in the left ventricle (9). Moreover, P-wave dispersion (PWD) is known to predict the development of AF (10). More recently, the index of cardiac electrophysiological balance (iCEB), calculated by dividing the QT interval by the QRS duration, has been shown to be a predictor of ventricular arrhythmias $(11,12)$.

Along with the changes observed in medical treatment, CVID awareness and the number of diagnosed patients are increasing day by day. Previously deceased due to various infectious diseases (brain abscess, endocarditis, pneumonia, etc.), antibiotic therapies and intravenous immunoglobulin treatments administered to these patients prolonged life expectancy. However, the effects of this disease, which can be a long chronic process, on the cardiovascular system are unknown. In our study, we aimed to investigate the effects of this disease on electrocardiography for the first time.

\section{Methods}

\section{Patient Population}

A total of 60 participants, including 30 patients who had undergone a cardiological examination for any reason and were being monitored for CVID and 30 healthy subjects who had been age and sex matched, were included in the study at the allergy and immunology clinic at our hospital. A standard 12-lead ECG was performed on the patients. The exclusion criteria were as follows: chronic renal failure; presence of electrolyte abnormalities; presence of active infection or malignancy; use of any drugs affecting the cardiac conduction system (treatment with beta-blockers, non-dihydropyridine calcium channel blockers or digital use) or use of prophylactic antibiotics with known efficacy on electrocardiography for protection from infections (erythromycin, azithromycin, etc.); regular use of an inhaler due to chronic obstructive pulmonary diseases; having undergone percutaneous coronary intervention or coronary artery bypass surgery for coronary artery disease; presence of documented AF; presence of a cardiac pacemaker; presence of a branch block on the ECG; presence of preexcitation syndromes; presence of left ventricular hypertrophy on an echocardiogram; and moderate or severe heart valve disease. Baseline demographic characteristics and electrocardiographic findings of the study population were recorded. Informed consent was obtained from all patients and healthy controls. The study was approved by the local ethics committee of Necmettin Erbakan University Faculty of Medicine the study was conducted according to the Declaration of Helsinki (decision no: 2019/1909).

\section{Assessment of Electrocardiographic Parameters}

A standard 12-lead surface ECG was performed after at least 1 hour of rest $(10 \mathrm{mV} / \mathrm{mm}$ and $25 \mathrm{~mm} / \mathrm{s}$ paper speed Marquette Case, Hellige Medical System, Cardiosmart Hellige Instrument Company, Freiburg, Germany). Heart rate, p-wave morphology, PR interval, QRS duration, QT distance and T-wave morphology were analyzed. All ECG samples were transferred to a digital platform to reduce the margin of error during measurement, and measurements were then taken using special software (Adobe Photoshop) to provide necessary magnification.

The beginning point of the P-wave was described as the first upward positive or downward negative deflection between the isoelectric line and the end of the P-wave was characterized as the point where the last deflection of the P-wave met the isoelectric line. Maximum $\mathrm{P}\left(\mathrm{P}_{\max }\right)$ and minimum $\mathrm{P}\left(\mathrm{P}_{\min }\right)$ wave durations were recorded. PWD was defined as the difference between the maximum and $P_{\text {min }}$-wave durations (10). Interatrial duration was regarded as the greatest duration of P-waves from D2, D3, AVF or V1 (13). P terminal force was defined as the terminal negative part of a biphasic $\mathrm{P}$-wave in lead $\mathrm{V} 1$ being greater than 1 small square $(40 \mathrm{~mm})$ (14). The QT interval was conventionally obtained by manually measuring from the onset of the QRS complex to the crossing point of the T wave and isoelectric line. The heart rate-corrected QT interval was calculated using Bazett's formula (CQT=QT $\sqrt{ }(\mathrm{R}-\mathrm{R}$ interval). QT dispersion (QTd) was obtained by measuring the longest QT interval $\left(\mathrm{QT}_{\max }\right)$ and the shortest $\mathrm{QT}$ interval $\left(\mathrm{QT}_{\min }\right)$ in any lead (15). QT interval measurements were taken by examining recordings from leads D2 and precordial V5, and the longer lead was recorded for statistical analysis (16). Changes in the T-wave in each cardiac cycle (shape, height, or duration) were termed macroscopic T-wave alternans (17). The distance from the peak of the T-wave $\left(T_{\text {peak }}\right)$ to the endpoint of the T-wave ( $T$ end) ( $T_{\text {peak-end }}$ or $\left.\mathrm{T}_{\mathrm{p}-\mathrm{e}}\right)$ was obtained from the chest leads. The $\mathrm{T}_{\mathrm{p}-\mathrm{e}} / \mathrm{QT}$ ratio was obtained by dividing the $\mathrm{T}_{\mathrm{p} \text {-e }}$ duration by the QT interval in the precordial V5 lead $(16,18)$. iCEB was obtained by dividing the QT interval by the QRS duration in the same lead (D2 or V5) $(11,12)$.

\section{Statistical Analysis}

SPSS ${ }^{\circledR}$ version 16.0 statistical package software (SPSS Inc., Chicago, IL, United States) was used for statistical analyses. We presented normally distributed quantitative variables as mean \pm standard deviation while we presented categorical variables in numbers and percentages. Normality of distribution was evaluated using the Kolmogorov-Smirnov test. Mean values of continuous variables were compared between independent groups using the Student's t-test, one-way ANOVA test, or Kruskal-Wallis test as appropriate. The chi-square test was performed to compare the study groups in terms of categorical variables. A p-value below 0.05 was considered statistically significant.

\section{Results}

The mean age of the patients included in the study was $38.76 \pm 13.59$ years and $57 \%(n=34)$ were male. In addition, there was no statistically significant difference between the groups (CVID group and control group) in terms of age, gender, hypertension and smoking ( $p>0.05)$. The mean age of patients with CVID at the time of initial diagnosis was calculated as $28.03 \pm 15.29$ years (minimum 1 year, maximum 60 years). The mean follow-up period of CVID patients was $8 \pm 6.58$ years while the rate of patients with bronchiectasis whose clinical condition was not affected was $47 \%(n=14)$ in this patient group. The main demographic and characteristic features of the study population are shown in Table 1.

Table 2 shows a comparison of electrocardiographic parameters of the patient and control groups. Accordingly, the heart rate per minute and 
$\mathrm{P}_{\text {max }}$ and $\mathrm{P}_{\text {min }}$ intervals were similar in both groups while the PR interval and PWD were found to be higher in the CVID group ( $p$ value; 0.009 and 0.005 , respectively). In addition, the QT interval and corrected QT interval were higher in the CVID arm $(p=0.021)$, and the iCEB value obtained with the QT/QRS ratio was also higher in the CVID group $(p=0.031)$. T peak-to-end interval was higher in the CVID group $(p=0.013)$ while the T peak-to-end/QT ratio was not statistically significant between the two groups although it was still high $(p=0.093)$. The number of patients with $P$ terminal force was higher in the CVID group ( $20 \%$ vs. $3 \%, p=0.044)$ while the number of patients monitored for macrovolt T-wave alternans was similar in both groups $(p=0.519)$.

Depending on the presence of bronchiectasis, the QT interval and corrected QT interval were found to be longer in the presence of bronchiectasis when the subgroup analysis of the CVID group was performed ( $p$ values $=0.011$ and 0.013 , respectively). All other electrocardiographic parameters were observed to be similar. Table 3 shows a comparison of the electrocardiographic parameters of the CVID group in the presence of bronchiectasis.

\section{Discussion}

As a result of our study, P-wave and QTd, a predictor of the development of arrhythmia in CVID patients, $\mathrm{T}_{\mathrm{p} \text {-e }}$ interval and index of cardiac electrophysiological balance values have been shown to be higher. In addition, the QT interval was longer and P-terminal force frequency was higher in this patient group. Furthermore, none of these results varied, except for the QT interval, with bronchiectasis that does not require clinical treatment.

In CVID patients, the disease is usually diagnosed within about 8 years after first symptoms, and this diagnostic delay results in delayed initiation of standard treatments (immunoglobulin), thereby increasing

\section{Table 1. Basale characteristic of study population}

\section{Variables}

Age (years, mean $\pm \mathrm{SD})$

Gender (male, n\%)

Diabetes Mellitus ( $\mathrm{n} \%)$

Hypertension (n\%)

Smoking (n\%)

Ejection fraction (\%, mean \pm SD)

Age of diagnosis (years, mean \pm SD, minimum-maximum)

Following period (years, mean $\pm \mathrm{SD}$ )

The usage time of intravascular immunglobuline (years, mean \pm SD)

CVID: common variable immunodeficiency, SD: standard deviation

\begin{tabular}{|l|l|l|}
\hline Control group $(\mathbf{n}=\mathbf{3 0})$ & CVID group $(\mathbf{n}=\mathbf{3 0})$ & $\mathbf{p}$ \\
\hline $40.70 \pm 13.85$ & $36.83 \pm 13.28$ & 0.274 \\
\hline $18(60)$ & $16(53.3)$ & 0.602 \\
\hline $3(10)$ & $2(6)$ & 0.640 \\
\hline $4(13)$ & $3(10)$ & 0.688 \\
\hline $8(26)$ & $6(20)$ & 0.542 \\
\hline $62.13 \pm 4.71$ & $63.33 \pm 3.45$ & 0.438 \\
\hline- & $28.03 \pm 15.29(1-60)$ & - \\
\hline- & $8 \pm 6.58$ & - \\
\hline- & $7.69 \pm 6.88$ & - \\
\hline
\end{tabular}

Table 2. Comparison of electrocardiographic parameters of the study group

\section{Variables}

Heart rate (beat/min, mean \pm SD)

PR interval (msn, mean \pm SD)

$\mathrm{P}$ maximum (msn, mean $\pm \mathrm{SD})$

$P$ minimum (msn, mean \pm SD)

$\mathrm{P}$ wave dispersion (msn, mean $\pm \mathrm{SD}$ )

Interatrial duration ( $\geq 110 \mathrm{~ms})(\mathrm{n} \%)$

P terminal force $(n, \%)$

QT duration (msn, mean \pm SD)

Corrected QT duration (msn, mean \pm SD)

QT dispersion (msn, mean \pm SD)

QRS duration (msn, mean \pm SD)

T peak to T-end interval (msn, mean \pm SD)

T peak to T-end interval/QT duration ratio

T peak to T-end interval/corrected QT duration ratio

Macrovolt T wave alternans ( $\mathrm{n} / \%)$

Index of cardioelectrophsiyological balance (QT interval/QRS duration ratio)

Corrected Index of cardioelectrophsiyological balance (corrected QT interval/QRS duration ratio)

CVID: Common variable immunodeficiency, SD: standard deviation

\begin{tabular}{|l|l|l|}
\hline Control group $(\mathbf{n}=30)$ & CVID group $(\mathbf{n}=30)$ & $\mathbf{p}$ \\
\hline $80.60 \pm 13.63$ & $84.86 \pm 15.24$ & 0.258 \\
\hline $135.13 \pm 13.76$ & $147.10 \pm 20$ & 0.009 \\
\hline $96.26 \pm 20.25$ & $101.83 \pm 22.9$ & 0.323 \\
\hline $51 \pm 16.62$ & $44.53 \pm 9.74$ & 0.071 \\
\hline $44.7 \pm 13.29$ & $57.8 \pm 20.38$ & 0.005 \\
\hline $8(27)$ & $10(33)$ & 0.389 \\
\hline $1(3.3)$ & $6(20)$ & 0.044 \\
\hline $360.17 \pm 22.14$ & $378.5 \pm 35.84$ & 0.021 \\
\hline $396.51 \pm 27.82$ & $419.38 \pm 30.34$ & 0.004 \\
\hline $31 \pm 12.06$ & $44.96 \pm 26.01$ & 0.011 \\
\hline $82.90 \pm 10.81$ & $77.66 \pm 14.82$ & 0.124 \\
\hline $68.5 \pm 12.87$ & $78.1 \pm 16.05$ & 0.013 \\
\hline $0.19 \pm 0.33$ & $0.20 \pm 0.04$ & 0.093 \\
\hline $0.17 \pm 0.33$ & $0.18 \pm 0.03$ & 0.185 \\
\hline $7(23)$ & $5(16)$ & 0.519 \\
\hline $4.41 \pm 0.64$ & $4.92 \pm 1.07$ & 0.031 \\
\hline $4.86 \pm 0.76$ & $5.44 \pm 1.24$ & 0.033 \\
\hline & & \\
\hline
\end{tabular}


Table 3. Comparison of CVID patients according to the presence of bronchiectasis

\begin{tabular}{|c|c|c|c|}
\hline Variables & $\begin{array}{l}\text { Patients with } \\
\text { bronchiectasia }(n=14)\end{array}$ & $\begin{array}{l}\text { Patients without } \\
\text { bronchiectasia }(n=16)\end{array}$ & $\mathbf{p}$ \\
\hline Age (years, mean \pm SD) & $36.5 \pm 13.71$ & $37.12 \pm 13.34$ & 0.912 \\
\hline Following period (years, mean \pm SD) & $9.66 \pm 6.53$ & $6.61 \pm 6.38$ & 0.206 \\
\hline The usage time of intravascular immunglobuline (years, mean \pm SD) & $9.26 \pm 6.13$ & $7.29 \pm 6.33$ & 0.037 \\
\hline PR interval (msn, mean \pm SD) & $147.29 \pm 20.93$ & $146.94 \pm 19.85$ & 0.963 \\
\hline $\mathrm{P}$ maximum (msn, mean $\pm \mathrm{SD})$ & $108.50 \pm 25.16$ & $96 \pm 19.69$ & 0.138 \\
\hline $\mathrm{P}$ minimum (msn, mean $\pm \mathrm{SD})$ & $46.92 \pm 12.33$ & $42.43 \pm 6.44$ & 0.213 \\
\hline P wave dispersion (msn, mean \pm SD) & $61.21 \pm 21.12$ & $54.81 \pm 19.91$ & 0.401 \\
\hline Corrected QT duration (msn, mean \pm SD) & $405.07 \pm 26.84$ & $431.91 \pm 28.68$ & 0.013 \\
\hline QT dispersion (msn, mean \pm SD) & $36.85 \pm 21.11$ & $52.06 \pm 28.41$ & 0.072 \\
\hline QRS duration (msn, mean \pm SD) & $77.28 \pm 10.17$ & $78 \pm 18.31$ & 0.898 \\
\hline T peak to T-end interval (msn, mean \pm SD) & $78.21 \pm 17.57$ & $78 \pm 15.19$ & 0.972 \\
\hline T peak to T-end interval/QT duration ratio & $0.21 \pm 0.04$ & $0.19 \pm 0.04$ & 0.233 \\
\hline T peak to T-end interval/corrected QT duration ratio & $0.19 \pm 0.04$ & $0.17 \pm 0.03$ & 0.353 \\
\hline Macrovolt T wave alternans (n, \%) & $3(21)$ & $2(14)$ & 0.743 \\
\hline Index of cardioelectrophsiyological balance (QT interval/QRS duration ratio) & $4.73 \pm 0.73$ & $5.08 \pm 1.3$ & 0.382 \\
\hline Corrected Index of cardioelectrophsiyological balance (corrected QT interval/QRS duration ratio) & $5.32 \pm 0.79$ & $5.54 \pm 1.55$ & 0.633 \\
\hline
\end{tabular}

mortality and morbidity rates of the disease (19). Although the life expectancy of CVID patients increases with improved treatment methods, the presence of chronic inflammation leads to the development of different diseases in this patient group $(20,21)$. In CVID patients, TNFalpha and CRP levels were found to be higher as indicators of chronic inflammation compared to healthy subjects. The clinical presentation of this disease is known to be more severe in patients with high inflammation parameters $(21,22)$. Inflammation parameters, such as TNF-alpha, CRP and IL-6 are also known to play an effective role in the pathogenesis of atherosclerosis which is a chronic disease. In addition, apo-A and high-density lipoprotein cholesterol levels and chronic inflammation were lower in this patient group (21). When evaluated with this evidence, atherosclerotic heart disease was considered to have started at an early stage in CVID patients and was thought to display a rapid course. On the other hand, it was thought that atherosclerosis and related diseases could be overlooked in these patients due to chronic respiratory infections (pneumonia, bronchiectasis, etc.), gastrointestinal system infections, autoimmune diseases and malignant diseases which are more common in early ages (23). As life expectancy was lower in this patient group, atherosclerotic cardiovascular diseases were thought to not display any clinical symptoms. In a comprehensive study, the age of mortality was shown to be between 40 and 50 years. However, with current immunoglobulin therapies and advanced antibiotic technologies, it is thought that the rate of patients presenting with cardiovascular diseases will increase in the near future $(23,24)$. Another hypothesis was described as follows: "Endothelial dysfunction and endothelial inflammation in atherosclerosis cannot develop due to chronic immune dysregulation and immunodeficiency or the risk of atherosclerosis in these patients is similar in healthy individuals due to received immunoglobulin treatments" (23).

As atherosclerosis itself is known to be a risk factor for cardiac arrhythmias, the increased inflammatory response itself has also been shown to cause cardiac arrhythmias alone. For instance, inflammatory markers such as TNF-alpha, CRP, IL 6-8 were found to be higher in individuals with AF (25). Individuals with high CRP levels following myocardial infarction were more likely to suffer from ventricular tachycardia during clinical follow-up (26). At this point, it can be considered that the chronic inflammatory process in CVID patients provides a suitable basis for the development of cardiac arrhythmias.

Various parameters have been developed in standard surface electrocardiography to predict cardiac arrhythmias and pathologies. The main purpose of this study was to evaluate the effect of CVID on these parameters and to assess the arrhythmogenic risk in this patient population. Here, P-wave dispersion, a strong predictor of 
the possibility of AF and the efficacy of which was demonstrated in various studies, was found to be higher in CVID patients $(10,27)$. This supports the inflammatory process and risk of developing AF in CVID patients. Interatrial duration (interatrial block) and p-terminal force are parameters that were indicative of dilatation and dysfunction of the left atrium, atrial fibrillation and development of stroke $(13,28,29)$. In our study, the frequency of P-terminal force was higher in CVID patients (3.3\% vs. $20 \%, p=0.044)$; however, no statistically significant difference was determined in interatrial duration although the number thereof was higher $(p=0.389)$. It should not be overlooked that the excess $P$ terminal force supports the high probability of developing AF in this patient group. In addition, increased QTd detected in a surface ECG is associated with increased heterogeneity in ventricular repolarization and has an adverse impact on the development of ventricular arrhythmia $(15,30)$. In our study, the QTd was higher in CVID. Moreover, iCEB, calculated as the QT/QRS interval, has been defined as a new risk predictor for malignant ventricular arrhythmias. Increased iCEB values have been shown to be associated with torsades de pointes while decreased iCEB values have been associated with non-torsades de pointes ventricular tachycardia or ventricular fibrillation $(11,12)$. Again, this value was higher in the CVID patient group ( $p=0.031)$. The high QTd and iCEB values indicate that the incidence of ventricular arrhythmia is higher in this patient group than in the normal population. In addition to this information, the $\mathrm{T}_{\mathrm{p} \text {-e }}$ interval is considered an index of transmural dispersion of repolarization in the left ventricle, and the $\mathrm{T}_{\mathrm{p}-\mathrm{e}} / \mathrm{QT}$ ratio is used as a newer electrocardiographic index showing ventricular arrhythmias. Accordingly, a prolonged $\mathrm{T}_{\mathrm{p} \text {-e }}$ interval and a higher $\mathrm{T}_{\mathrm{p} \text {-e }} / \mathrm{QT}$ ratio were associated with an increased risk of ventricular arrhythmia $(9,31)$. In our patients, an increased $T_{p-e}$ interval supported the risk of ventricular arrhythmia $(p=0.013)$ while no statistical significance was observed $(p=0.185)$ with an increased $\mathrm{T}_{\mathrm{p}-\mathrm{e}} / \mathrm{QT}$ ratio.

The incidence of lung pathologies, particularly bronchiectasis, is high in CVID patients due to delayed diagnosis and treatment. Bronchiectasis is the most common pulmonary pathology in this patient group with a prevalencevarying between 17 and $76 \%(32,33)$. In our patient population, this rate was $46.6 \%$. There was no significant difference upon review of the ECGs of CVID patients with and without bronchiectasis. In patients with bronchiectasis, only the QT interval was shorter. Furthermore, as expected, the follow-up and treatment periods were slightly longer in the bronchiectasis group. Essentially, electrocardiographic changes should be more significant in the bronchiectasis group due to the longer duration of disease in patients with bronchiectasis. However, the small number of patients may be the most effective parameter to cause this condition. The high QT interval in CVID patients without bronchiectasis may be a coincidental result. More comprehensive and detailed studies are necessary to clarify this situation.

\section{Conclusions}

As a result of this study, it has been found that CVID patients have a higher incidence of developing arrhythmia than normal healthy individuals. Similar studies with a larger number of participants and longer follow-up period are needed to support our findings.
Ethics Committee Approval: The study was approved by the local ethics committee of Necmettin Erbakan University Faculty of Medicine the study was conducted according to the Declaration of Helsinki (decision no: 2019/1909).

Informed Consent: Informed consent was obtained from all patients and healthy controls.

Peer-review: Externally peer-reviewed.

Author Contributions: Surgical and Medical Practices - Y.A., F.C..; Concept - Y.A., F.Ç.; Design - Y.A., F.Ç.; Data Collection and/or Processing - Y.A., F.C..; Analysis and/or Interpretation - Y.A., F.C..; Literature Search Y.A., F.Ç.; Writing Manuscript - Y.A., F.C..

Conflict of Interest: No conflict of interest was declared by the authors.

Financial Disclosure: The authors declared that this study received no financial support.

\section{References}

1. Park MA, Li JT, Hagan JB, Maddox DE, Abraham RS. Common variable immunodeficiency: a new look at an old disease. Lancet 2008; 372: 489-502.

2. Cunningham-Rundles C, Knight AK. Common variable immune deficiency:reviews, continued puzzles, and a new registry. Immunol Res 2007; 38: 78-86.

3. Gathmann B, Mahlaoui N, Gérard L, Oksenhendler E, Warnatz K, Schulze I, et al. Clinical picture and treatment of 2212 patients with common variable immunodeficiency. J Allergy Clin Immunol 2014; 134: 116-26.

4. Human A, Murguia FL, Benson L, Roifman I, Grunebaum E. Cardiovascular abnormalities in primary immunodeficiency diseases. LymphoSign Journal 2015; 2: 107-34.

5. Libby $\mathrm{P}$, Okamoto $\mathrm{Y}$, Rocha VZ, Folco E: Inflammation in atherosclerosis: transition from theory to practice. Circ J 2010; 74: 213-20.

6. Fujiki A, Sakamoto T, Nishida K, Mizumaki K, Inoue H. Relation of interleukin-6 and C-reactive protein levels to sinus maintenance after pharmacological cardioversion in persistent atrial fibrillation. J Cardiovasc Pharmacol 2007; 50: 264-6.

7. Sata N, Hamada N, Horinouchi T, Amitani S, Yamashita T, Moriyama Y, et al. C-reactive protein and atrial fibrillation. Is inflammation a consequence or a cause of atrial fibrillation? Jpn Heart J 2004; 45: 441-5.

8. Straus SM, Kors JA, De Bruin ML, van der Hooft CS, Hofman A, Heeringa J, et al. Prolonged QTC interval and risk of sudden cardiac death in a population of older adults. J Am Coll Cardiol 2006; 47: 362-7.

9. Gupta P, Patel C, Patel H, Narayanaswamy S, Malhotra B, Green JT et al. T(p-e)/ QT ratio as an index of arrhythmogenesis. J. Electrocardiol 2008; 41: 567-74.

10. Dilaveris PE, Gialafos EJ, Sideris SK, Theopistou AM, Andrikopoulos GK, Kyriakidis M, et al. Simple electrocardiographic markers for the prediction of paroxysmal idiopathic atrial fibrillation. Am Heart J 1998; 135: 733-8.

11. Lu HR, Yan GX, Gallacher DJ. A new biomarker-index of cardiac electrophysiological balance (iCEB)-plays an important role in drug-induced cardiac arrhythmias: Beyond QT-prolongation and torsades de pointes (TdPs). J Pharmacol Toxicol Methods 2013; 68: 250-9.

12. Robyns T, Lu HR, Gallacher DJ, Garweg C, Ector J, Willems R et al. Evaluation of Index of Cardio-Electrophysiological Balance (iCEB) as a New Biomarker for the Identification of Patients at Increased Arrhythmic Risk. Ann Noninvasive Electrocardiol 2016; 21: 294-304.

13. Goyal Sb, Spodıck Dh. Electromechanical dysfunction of the left atrium associated with interatrial block. Am Heart J 2001; 142: 823-7. 
14. E.W. Hancock, B.J. Deal, D.M. Mirvis, Okin P, Kligfield P, Gettes LS, et al. American Heart Association Electrocardiography and Arrhythmias Committee, Council on Clinical Cardiology; American College of Cardiology Foundation; Heart Rhythm Society, et al. AHA/ACCF/HRS recommendations for the standardization and interpretation of the electrocardiogram J. Am. Coll. Cardiol 2009; 53: 992-1002.

15. Malik M and Batchvarov VN. Measurement, interpretation and clinical potential of QT dispersion. J Am Coll Cardiol 2000; 36: 1749-66.

16. Shimizu M, Ino H, Okeie K, Yamaguchi M, Nagata M, Hayashi K, et al. T-peak to T-end interval may be a better predictor of high-risk patients with hypertrophic cardiomyopathy associated with a cardiac troponin I mutation than QT dispersion. Clin Cardiol 2002; 25: 335-9.

17. Narayan SM. T-wave alternans and the susceptibility to ventricular arrhythmias. J Am Coll Cardiol 2006; 47: 269-81.

18. Castro Hevia J, Antzelevitch C, Tornés Bárzaga F, Dorantes Sánchez M, Dorticós Balea F, Zayas Molina R, et al. Tpeak-Tend and Tpeak-Tend dispersion as risk factors for ventricular tachycardia/ventricular fibrillation in patients with the Brugada syndrome. J Am Coll Cardiol 2006; 47: 1828-34.

19. Seymour B, Miles J, Haeney M. Primary antibody deficiency and diagnostic delay. J Clin Pathol 2005; 58: 546-7.

20. Frostegard J. Immunity, atherosclerosis and cardiovascular disease. BMC Med 2013; 11: 117.

21. Vieira DG, Costa-Carvalho BT, Hix S, da Silva R, Correia MS, Sarni RO. Higher Cardiovascular Risk in Common Variable Immunodeficiency and X-Linked Agammaglobulinaemia Patients. Ann Nutr Metab 2015; 66: 237-41.

22. Trujillo CM, Muskus C, Arango J, Patino PJ, Montoya CJ. Quantitative and functional evaluation of innate immune responses in patients with common variable immunodeficiency. J Investig Allergol Clin Immunol 2011; 21: 20715.
23. Ucar R, Arslan S, Turkmen K, Calıskaner AZ. Accelerated atherosclerosis in patients with common variable immunodeficiency: Is it overlooked or absent?. Med Hypotheses 2015; 85: 485-7.

24. Resnick ES, Moshier EL, Godbold JH, Cunningham-Rundles C. Morbidity and mortality in common variable immune deficiency over 4 decades. Blood 2012; 119: 1650-7.

25. Harada M, Van Wagoner DR, Nattel S. Role of inflammation in atrial fibrillation pathophysiology and management. Circ J 2015; 79: 495-502.

26. Blangy H, Sadoul N, Dousset B, Radauceanu A, Fay R, Aliot E, et al. Serum BNP, hs-CRP, procollagen to assess the risk of ventricular tachycardia in ICD recipients after myocardial infarction. Europace 2007; 9: 724-9.

27. Dilaveris PE, Gialafos JE. P-wave dispersion: a novel predictor of paroxysmal atrial fibrillation. Ann Noninvasive Electrocardiol 2001; 6: 159-65.

28. Agarwal Yk, Aronow Ws, Levy Ja, Spodıck Dh. Association of interatrial block with development of atrial fibrillation. Am J Cardiol 2003; 91: 882.

29. Spodıck Dh, Arıyarajah V, Goldberg R. Interatrial block: correlation with Pterminal force. Clin Cardiol 2009; 32: 181-2.

30. Lee KW, Okin PM, Kligfield P, Stein KM, Lerman BB. Precordial QT dispersion and inducible ventricular tachycardia. Am Heart J 1997; 134: 1005-13.

31. Hetland M, Haugaa KH, Sarvari SI, Erikssen G, Kongsgaard E, Edvardsen T. A novel ECG-index for prediction of ventricular arrhythmias in patients after myocardial infarction. Ann. Noninvasive Electrocardiol 2014; 19: 330-7.

32. Maarschalk-Ellerbroek LJ, Hoepelman AI, van Montfrans JM, Ellerbroek PM. The spectrum of disease manifestations in patients with common variable immunodeficiency disorders and partial antibody deficiency in a university hospital. J Clin Immunol 2012; 32: 907-21.

33. Ardeniz O, Başoğlu OK, Günșar F, Unsel M, Bayraktaroğlu S, Mete N, et al. Clinical and immunological analysis of 23 adult patients with common variable immunodeficiency. J Investig Allergol Clin Immunol 2010; 20: 222-36. 